\title{
Penurunan Tingkat Depresi Pada Lansia dengan Terapi Reminiscence
}

\author{
Sonhaji ${ }^{1}$, Heni Wijayanti ${ }^{1}$, Nurul Ainun Nafisah ${ }^{1}$ \\ ${ }^{1}$ Universitas Karya Husada Semarang (Keperawatan, Keperawatan dan Kesehatan, Semarang) \\ Corresponding author: soni aji84@vahoo.com
}

\begin{abstract}
ABSTRAK
Latar Belakang: pertambahan usia akan menimbulkan perubahan-perubahan fisik dan struktur dan kemunduran fungsi.Masalah lansia yang sering yaitu kurangnya kemampuan dalam beradaptasi terhadap perubahan psikologis sehingga lansia akan mengalami gangguan psikologis salah satunya yaitu depresi.

Tujuan: mengetahui pengaruh terapi Reminiscence Terhadap Tingkat Depresi pada Lansia di Rw 03 Desa Pojok Wilayah Kerja Puskesmas Pulokulon 2 Kabupaten Grobogan.

Metode: jenis penelitian pre ekperiment dengan pendekatan one group pre-test and post-test design. Sampel sebanyak 16 responden. Analsia data pada penelitian ini dilakukan analisa data menggunakan uji t berpasangan (Paired $t$-Test).

Hasil: tingkat depresi sebelum diberikan terapi Reminiscence pada lansia menunjukkan nilai rata-rata 6,25 sedangkan tingkat deperesi sesudah di diberikan terapi Reminiscence menunjukkan nilai rata-rata 2,94 yang berarti mengalami penurunan dengan $\mathrm{p}$ _value $=$ $0,000<0,05$.
\end{abstract}

Kesimpulan: ada pengaruh terapi reminiscence terhadap penurunan tingkat depresi pada lansia dengan $\mathrm{p} \_$value $=0,000$.

Saran: Memberikan bimbingan dan arahan kepada lansia dan keluarga untuk melakukan kegiatan terapi reminiscance untuk mengurangi tingkat depresi pada lansia secara mandiri.

Kata Kunci : Lansia,tingkat depresi,terapi Reminiscenc

\begin{abstract}
Background: increasing age will cause physical and structural changes and a decline in function. The problem of the elderly that often is the lack of ability to adapt to psychological changes so that the elderly will experience psychological disorders, one of which is depression.

Purpose: to determine the effect of reminiscence therapy on depression levels in the elderly in Rw 03 Pojok Village, Pulokulon 2 Health Center Working Area, Grobogan Regency.
\end{abstract}


Methods: pre-experimental research with a one-group pre-test and post-test design approach. The sample is 16 respondents. Data analysis in this study was analyzed using paired t-test (Paired t-Test).

Results: the level of depression before being given Reminiscence therapy in the elderly showed an average value of 6.25 while the level of depression after being given Reminiscence therapy showed an average value of 2.94 which means it decreased with p_value $=0.000<0.05$.

Conclusion: there is an effect of reminiscence therapy on decreasing depression levels in the elderly with $\mathrm{p} \_$value $=0.000$.

Suggestion: Provide guidance and direction to the elderly and their families to carry out reminiscance therapy activities to reduce the level of depression in the elderly independently.

\section{Keywords:}

Elderly, level of depression, Reminiscence therapy

\section{LATAR BELAKANG}

Lansia didefinisikan sebagai seseorang yang telah mencapai usia lebih dari 60 tahun, sedangkan World Health Organization (WHO) mendefinisikan lansia adalah sebagai sekelompok penduduk yang berusia 65 tahun keatas Berdasarkan sensus data Badan Pusat Statistika (BPS) di Indonesia pada tahun 2019 jumlah lansia di indonesia mencapai 25 juta-an (96\%) . Pada tahun 2020 jumlah lansia mencapai 26 juta-an $(9,92$ $\%$ ),ada enam provinsi yang memiliki presentase lansia terbanyak di Indonesia pada tahun 2020, yaitu: DI Yogyakarta (14,71 \%), Jawa Tengah (13,81 \%), Jawa Timur (13,38), Bali (11,58 \%), Sulawesi Utara (11,51\%), dan Sumatera Barat $(10,07 \%)$ (Avenzora, 2020).

Pertambahan usia akan menimbulkan perubahan-perubahan fisik dan struktur dan kemunduran fungsi. Kemunduran fungsi organ tubuh khususnya pada lansia menyebabkan lansia rawan terhadap berbagai masalah kesehatan. Masalah lansia yang sering yaitu kurangnya kemampuan dalam beradaptasi terhadap perubahan psikologis sehingga lansia akan mengalami gangguan psikologis salah satunya yaitu depresi (Azizah, 2021).

Depresi pada lansia disebabkan oleh stress dalam menghadapi perubahan-perubahan kehidupan seperti masa pensiun yang terpaksa, kematian pasangan, kemunduran kemampuan atau kekuatan fisik dan kemunduran kesehatan serta penyakit fisik, kedudukan sosial, keuangan, penghasilan. Gejala depresi ditandai dengan kesedihan, hargadiri rendah, rasa bersalah, putusasa, dan perasaan kosong.. Dampak yang timbul pada lansia yang depresi terlihat dari perilaku mereka yang sering mengalami gangguan tidur, lelah, lemas, kurang bersemangat, merasa tidak berguna (Keliat, 2011).

Dukungan keluarga sangat diperlukan pada lansia yang mengalami gangguan psikologis, hal ini bertujuan untuk menurunkan kejadian yang mengakibatkan stress, 
karena interaksi dengan orang lain atau dengan keluarga mampu memodifikasi persepsi seseorang terhadap suatu kejadian sehingga mengurangi potensi terjadinya stress (Niken,2016). Dukungan keluarga pada lansia memberikan ketenangan batin, ketentraman batin dan pengaruh positif pada lansia, dukungan keluarga sangat diperlukan lansia untuk meningkatkan kebahagian lansia dalam melakukan aktivitasnya, kepercayaan diri yang dimiliki lansia dapat kembali dengan dukungan keluarga yang baik, lansia yang tinggal dengan keluarga mempunyai kebahagiaan yang lebih tinggi disbanding lansia yang tinggal sendiri, lansia yang mempunyai dukungan yang baik akan merasa dihargai, dicintai dan diperhatikan sehingga kualitas hidup lansia akan meningkat (Maryam, 2018).

Adapun cara mengatasi deprsi pada lansia dapat dikelola dengan tindakan perawatan farmakologi dan perawatan nonframakolgi. Salah satu terapi nonfarmakologi adalah Reminiscence Therapy. Reminiscence Therapy merupakan suatu metode yang berhubungan dengan memori,yang berguna untuk meningkatkan kesehatan mental dan kualitas hidup lansia (Maryam, 2018). Terapi ini dapat diimpementasikan dalam bentuk kelompok struktur,dalam kelompoktidak terstruktur atau secara individual (Avenzora, 2020). Terapi Reminiscence adalah proses mengingat peristiwa atau pengalaman lansia dan lansia dapat berfikir kembali dan dapat mengklarifikasi pengalaman sebelumnya dan berbicara tentang kehidupannya (Marianne H, 2013). Meninjau kehidupan dan menceritakan kisah-kisah lansia membuat lansia merasa puas dengan kehidupan dan benar-benar menghubungkan masalalu lansia dengan masa kini dan satu generasi kegenerasi lainnya. Reminiscence telah dilihat sebagai kegiatan terapi yang bermanfaat dan berpotensi untuk orang-orang dari segalausia. Namun ada kebutuhan untuk lebih banyak studi kasus terkontrol untuk membuktikan efektivitas jangka panjang yang sama (Yen, 2018)

Berdasarkan hasil survai dengan wawancara yang dilakukan oleh peneliti terhadap lansia di Rw 03 Desa Pojok Wilayah Kerja Puskesmas Pulokulon 2 Kabupaten Grobogan. Menyatakan bahwa 5 dari 10 lansia mengalami depresi setelah diukur dengan GDS (gariatric depression scale) mengalami depresi sedang dikarenakan merasa kesepian,sulit tidur,gelisah,merindukan kelurganya,mudah lupa,kehilangan pasangan dan merasa sudah tidak di dipedulikan dengan anak-anaknya atau keluarganya.

Berdasarkan data serta fenomena diatas peneliti tertarik untuk melakukan penelitian dengan judul "Pengaruh terapi Reminiscence Terhadap Tingkat Depresi pada Lansia di Rw 03 Desa Pojok Wilayah Kerja Puskesmas Pulokulon 2 Kabupaten Grobogan".

\section{TUJUAN}

Mengetahui Pengaruh terapi Reminiscence Terhadap Tingkat Depresi pada Lansia di Rw 03 Desa Pojok Wilayah Kerja Puskesmas Pulokulon 2 Kabupaten Grobogan.

\section{METODE}

Jenis penelitian ini adalah penelitian kuantitatif dengan pendekatan Pre Eksperiment. Desain dalam penelitian ini menggunakan one group pre-test and post-test design. Teknik sampling yang digunakan dalam penelitian ini adalah purposive random 
sampling. Populasi dalam penelitian ini sebanyak 30 lansia. Sampel penelitian sebanyak 16 responden. Instrumen yang digunakan penelitian ini berupa SOP Terapi Reminisence. Analisadata pada penelitian ini dilakukan analisa data menggunakan uji t berpasangan (Paired $t$-Test) (Nursalam, 2014).

\section{HASIL}

Tabel 1.Tingkat Depresi Pada Lansia Di Rw 03 Desa Pojok Wilayah Kerja Puskesmas Pulokulon 2 Kabupaten Grobogan

\begin{tabular}{ccccccc}
\hline $\begin{array}{l}\text { Tingkat } \\
\text { Depresi }\end{array}$ & N & Mean & Median & $\begin{array}{c}\text { St. } \\
\text { Deviasi }\end{array}$ & Min & Max \\
\hline Sebelum & 16 & 6,25 & 6,00 & 1,125 & 5 & 8 \\
Sesudah & 16 & 2,94 & 3,00 & 0,854 & 1 & 4 \\
\hline
\end{tabular}

Dari 16 responden yang diteliti pada lansia di Rw 03 Desa Pojok Wilayah Kerja Puskemas Pulokulon 2 Kabupaten Grobogan di dapatkan nilai rata-rata (mean) dari penurunan tingkat depresi sebelum diberikan terapi reminiscence adalah 6,25 ; nilai tengah (median) 6,00; nilai standart deviasi 1,125; nilai terendah (minimum) 5; nilai tertinggi (maximal) 8. Nilai rata-rata (mean) dari penurunan tingkat depresi pada lansia di Rw 03 Desa Pojok Wilayah Kerja Puskemas Pulokulon 2 Kabupaten Grobogan sesudah diberikan terapi reminiscence adalah 2,94, nilai tengah (median) 3,00; nilai standart deviasi 0,854; nilai terendah (minimum) 1; nilai tertinggi (maximal) 4

Tabel 2. Uji Normalitas tingkat depresi sebelum dan sesudah

\begin{tabular}{lll}
\hline Tingkat Depresi & Uji Normalitas & $\mathrm{N}$ \\
\hline $\begin{array}{l}\text { Tingkat depresi sebelum } \\
\text { dilakukkan terapi } \\
\text { reminiscence }\end{array}$ & 0,018 & 16 \\
\hline $\begin{array}{l}\text { Tingkat depresi sesudah } \\
\text { dilakukkan terapi reminiscence }\end{array}$ & 0,019 & 16 \\
\hline
\end{tabular}

Penelitian ini dilakukan uji normalitas distribusi data, karena jumlah sample $16<50$ sampel, maka diambil signifikasi Shapiro Wilk. Tabel menunjukkan hasil uji distribusi data untuk tingkat depresi sebelum diberikan terapi reminiscence adalah 0,18 , diasumsikan $<0,05$ yang artinya data berdistribusi tidak normal dan hasil uji distribusi data untuk tingkat depresi sesudah diberikan terapi reminiscence adalah 0,19 diasumsikan $<0,05$ yang artinya data berdistribusi tidak normal, maka jenis data dan analisa data yang digunakan yaitu uji wilcoxon. 
Tabel 3. Pengaruh Terapi Reminiscence Terhadap Penurunan Tingkat Depresi Pada Lansia di Rw 03 Desa Pojok Wilayah Kerja Puskesmas Pulokulon 2 Kabupaten Grobogan

\begin{tabular}{cccc}
\hline Tingkat Depresi & $\mathrm{N}$ & Mean Rank & $\begin{array}{c}\mathrm{P} \\
\text { Value }\end{array}$ \\
& & &, 000 \\
Sebelum & 16 & 8,50 & \\
Sesudah & &, 00 & \\
\hline
\end{tabular}

Berdasarkan distribusi data diatas tingkat depresi sebelum diberikan terapi reminiscence menunjukka nilai mean rank 8,50. Serta nilai mean ranktingkat depresi sesudah diberikan terapi reminiscence sebesar 0,00 , karena data yang didapat berdistribusi tidak normal maka dilakukan uji wilcoxon di dapat $p \_$value 0,000 yang artinya $<0,05$, maka dapat disimpulkan Ha diterima dengan kesimpulan Pengaruh Terapi Reminiscence Terhadap Penurunan Tingkat Depresi Pada Lansia di Rw 03 Desa Pojok Wilayah Kerja Puskesmas Pulokulon 2 Kabupaten Grobogan

\section{PEMBAHASAN}

Berdasarkan hasil penelitian didapatkan hasil uji statistic diperoleh $(<0,05)$ sehingga menunjukan bahwa ada Pengaruh Terapi Reminiscence Terhadap Penurunan Tingkat Depresi Pada Lansia di Rw 03 Desa Pojok Wilayah Kerja Puskesmas Pulokulon 2 Kabupaten Grobogan. Lansia merupakan kelompok yang kepekaan dan kerentanannya sangat tinggi terhadap gangguan kesehatan sebagai akibat menurunnya fungsi dan kekuatan fisik dan fungsi kognitif, sumber finansial yang tidak memadai dan isolasi sosial. Rasa kurang percaya diri atau tidak berdaya dan menganggap bahwa hidupnya telah gagal karena harus mengahabiskan sisa hidupnya jauh dari orang-orang yang dicintai mengakibatkan lansia memandang masa depan suram dan menyesali diri sehingga mempengaruhi kemampuan lansia dalam beradaptasi terhadap situasi baru. ( Corey, Gerald, 2013)

Upaya penanggulangan depresi pada lansia salah satunya dengan Reminiscence Therapy (mengenang masa lalu yang menyenangkan). Reminiscence Therapy juga bertujuan untuk meningkatkan harga diri dan membantu mencapai kesadaran diri dan memahami diri, beradaptasi terhadap stress. Terapi ini dapat memotivasi lansia untuk mengingat pikiran, perasaan dan peristiwa masa lalu dan menyampaikan hal yang berharga bagi dirinya, menceritakan hobi dan prestasi yang pernah diraih, dengan demikian lansia dapat melupakan berbagai hal yang tidak menyenangkan dalam kehidupannya saat ini. Hal tersebut dapat mengurangi emosi negatif yang dirasakan dan meningkatkan mood positif. Intervensi dilakukan secara kelompok dapat memberikan kesempatan kepada lansia dalam membagi pengalamannya, meningkatkan sosialisasi dan komunikasi, serta menghemat biaya dan waktu. Pengaturan waktu dan pembagian kelompok yang tepat yaitu selama 60 menit dalam sekali intervensi, manajemen waktu yang cukup kepada setiap responden untuk bercerita, mendengarkan, dan memberikan feedback, serta pemakaian metode Simple atau Positive Reminiscence yaitu menceritakan kejadian masa lalu yang menyenangkan sehingga dapat memberikan efek yang positif terhadap 
responden juga merupakan beberapa faktor yang dapat mempengaruhi berhasilnya Reminiscence Therapy (Hawari, 2013)

Pada kelompok intervensi terdapat perubahan setelah diberikan Reminiscence Therapy dari depresi ringan menjadi tidak ada depresi, disebabkan karena Reminiscence Therapy fokus terhadap peristiwa-peristiwa yang menyenangkan pada lansia, sehingga dengan menceritakan dan mendiskusikan hal tersebut lansia menjadi senang, bangga dapat meningkatkan integritas diri dan mendapatkan penguatan positif sehingga mampu mengeliminasi peristiwa yang tidak menyenangkan. Melalui Reminiscence Therapy (mengenang masa lalu yang menyenangkan) lansia dirangsang atau dimotivasi untuk mendiskusikan kejadian atau peristiwa yang menyenangkan pada masa lalu sehingga membangkitkan perasaan atau emosi positif pada lansia. Pada saat peneliti memberikan terapi didalam proses penelitian tidak didapatkan lansia yang bersedih saat dilakukkan terapi,karena lansia merasa senang pada saat diajak bercerita tentang hal-hal yang menyenangkan. (Sunarti, 2019)

Hasil penelitian ini diperkuat oleh penelitian yang telah dilakukan oleh Syarniah (2014) juga menyebutkan bahwa Reminiscence Therapy dapat digunakan untuk menurunkan tingkat depresi sebesar 6,37 point (42,5\%). Terapi modalitas selain Reminiscence Therapy salah satunya adalah Cognitive Behavioral Therapy (CBT). Kedua terapi ini sama-sama mengacu pada aspek kognitif atau pikiran, yaitu merubah pikiran negatif menjadi positif. CBT terbukti dapat menurunkan tingkat depresi setelah diberikan intervensi selama 6 sesi sebesar 51 poin. CBT berhasil dalam menurunkan tingkat stress karena dapat membantu pasien dalam mengidentifikasi pikiran-pikiran negatif, mengenali faktor apa saja yang menyebabkan depresi, dan menangani depresi tersebut. (Hawari, 2013)

Menurut asumsi peneliti, dengan dilakukannya Reminiscence Therapy terbukti efektif bisa menurunkan tingkat depresi pada lansia sehingga meningkatkan keberhasilan dan kualitas terapi untuk menurunkan tingat depresi, hal ini juga berkaitan dengan hasil peneliti di atas, bahwa jika Reminiscence Therapy dapat meningkatkan nilai kognitif pada lansia itu juga akan mempengaruhi penurunan tingkat depresi pada lansia sehingga lansia bisa menilai koping adaptif mana yang sebaiknya yang harus digunakan. Melalui terapi ini, lansia dapat menemukan kelebihan dalam dirinya, membangun rasa kepercayaan diri lansia dan mengembangkan pemikiran positif dari lansia itu sendiri. Hal itu dapat meningkatkan harga diri lansia. Pemberian Reminiscence Therapy untuk mengatasi depresi pada lansia memang cukup penting mengingat efek negative depresi tersebut (Tamher, 2009). Berdasarkan hasil penelitian, Reminiscence Therapy cocok untuk diterapkan pada lansia, karena terapi ini merupakan terapi yang mudah untuk dilakukan. Terapi ini dapat dilakukan baik secara terstruktur maupun tidak terstruktur. Dalam lingkungan sehari-hari lansia dapat melakukan kegiatan mengenang bersama temanteman lansia lainnya (Fatma, 2018).

Mengatasi permasalahan depresi pada lansia salah satunya dengan Reminiscence Therapy (mengenang masa lalu yang menyenangkan) (Fatma, 2018). Reminiscence Therapy juga bertujuan untuk meningkatkan harga diri dan membantu mencapai 
kesadaran diri dan memahami diri, beradaptasi terhadap stress. Terapi ini dapat memotivasi lansia untuk mengingat pikiran, perasaan dan peristiwa masa lalu dan menyampaikan hal yang berharga bagi dirinya, menceritakan hobi dan prestasi yang pernah diraih, dengan demikian lansia dapat melupakan berbagai hal yang tidak menyenangkan dalam kehidupannya saat ini. Hal tersebut dapat mengurangi emosi negatif yang dirasakan dan meningkatkan mood positif (Niken, 2016)

Penelitian ini sejalan dengan Cahyono,dkk (2021) tentang pengaruh erapi reminiscence terhadap penurunan tingkat depresi pada lanisa, menunjukkan bahwa nilai sebelum diberikan terapi reminiscence rata-rata 5,25 sedangkan setelah diberikan terapi reminiscence nilai rata-rata berubah menajadi 3,03. Sehingga daat disimpulkan ada perubahan pengaruh terapi reminiscence terhadap penurunan tingkat depresi pada lansia diperoleh nilai $p_{-}$value $0,000<$ alpha $(0,05)$ (Cahyono.dkk, 2021)

\section{SIMPULAN}

Ada Pengaruh Terapi Reminiscence Terhadap Penurunan Tingkat Depresi Pada Lansia di Rw 03 Desa Pojok Wilayah Kerja Puskesmas Pulokulon 2 Kabupaten Grobogan dengan $p \_$value 0,000

\section{REFERENSI}

Avenzora, A. (2020). Statistika Penduduk Lanjut Usia. Badan Pusat Statistika.

Azizah, L. M. (2011). Keperawatan Lanjut Usia. Yogyakarta: Graha Ilmu.

Cahyono.dkk. (2021). Penerapan Reminiscence Therapy dalam Menurunkan Tingkat Depresi Lansia di Kabupaten Lombok Barat. Heaalt Information.

Corey, Gerald ( 2013). Teori dan Praktek Konseling \&Psikoterapi. Terjemahan E. Koswara, Bandung: Refika Aditama

Fatma, Mia,E.dkk.(2018). Meningkatkan Kualitas Hidup Lansia Konsep Dan Berbagai Strategi Intervensi. Malang : Wineka Media.

Hawari, D. (2013). Manajemen Stres Cemas dan Depresi. Jakarta: Fakultas Kedokteran Universitas Indonesia.

Keliat, B. A. (2011). Keperawatan Kesehatan Jiwa Komunitas CMHN .Jakarta: EGC.

Marianne H. Mitchell. (2013). Bimbingan dan Konseling, Yogyakarta : Pustaka Pelajar

Maryam, R. dkk ( 2018). Mengenal Usia Lanjut, Jakarta : Salemba Medika

Niken, A. (2016). Pengaruh Reminiscence Therapy Terhadap Tingkat Stress Pada Lansia Di Pstw Unit Budi Luhur, Kasongan, Bantul. Program Studi Ilmu Keperawatan Universitas Muhammdiyah Yogyakarta.

Nursalam (2014). Konsep dan Penerapan Metodologi Penelitian Ilmu Keperawatan Pedoman Skrispsi, Tesis dan Instrument Penelitian, Jakarta: Salamba Medika

Syarniah. (2010). Pengaruh Terapi Kelompok Reminiscence Terhadap Depresi Lansia Di Panti Sosial Tresna Werdha Budi Sejahtera. Tesis. Provinsi Kalimantan Selatan

Sunarti,Sri. dkk. (2019).Prinsip Dasar Kesehatan Lanjut Usia (Geriatri). Malang: UB Press

Tamher, S., dan Noorkasiana.(2009). Kesehatan Usia Lanjut Dengan Asuhan Keperawatan. Jakarta : Selemba Medika

Yen, H.-Y., \& Lin, L.-J. (2018). A Systematic Review of Reminiscence Therapy for

Older Adults in Taiwan: Journal of Nursing Research, 26(2), 138-150 